\title{
Optimal Configuration of a Solar Heating System with Seasonal Thermal Energy Storage Serving a Micro-scale Italian Residential District: Energy, Environmental and Economic Analyses
}

\author{
Antonio Rosato, Antonio Ciervo*, Giovanni Ciampi, Michelangelo Scorpio, Sergio Sibilio \\ Department of Architecture and Industrial Design, University of Campania "Luigi Vanvitelli", 81031 Aversa (CE), Italy
}

Corresponding Author Email: antonio.ciervo@unicampania.it

https://doi.org/10.18280/ti-ijes.642-404

Received: 16 March 2020

Accepted: 27 May 2020

\section{Keywords:}

solar energy, district heating, borehole thermal energy storage, storage design, energy saving, TRNSYS

\begin{abstract}
A centralized solar hybrid heating system serving a micro-scale district composed of 6 typical Italian residential buildings and 3 schools located in Naples (southern Italy) has been modelled, simulated and analyzed by means of the dynamic software TRNSYS over a 5year period. The plant is based on the operation of solar thermal collectors connected to a seasonal single U-pipe vertical Borehole Thermal Energy Storage (BTES) in order to address the seasonal misalignment between solar energy supply and thermal energy demand for heating purposes. In this paper, a parametric analysis has been performed in order to investigate the performance of the plant upon varying the characteristics of the BTES in terms of: (i) thermal conductivity of soil, (ii) thermal conductivity of grout, (iii) U-pipe spacing, (iv) heat carrier fluid, (v) number of Borehole Heat Exchangers (BHEs), as well as (vi) type of BHEs connection (series, parallel or mixed). The primary energy consumption, the equivalent carbon dioxide emissions and the operating costs of the proposed district heating network have been evaluated based on the simulation results upon varying the plant configurations and then compared with those associated to a conventional Italian decentralized heating system assumed as reference in order to (i) assess the potential benefits, (ii) explore the influence of BTES configuration on the overall system performance, and (iii) establish some simple rules for the initial phase of BTES design.
\end{abstract}

\section{INTRODUCTION}

District Heating Systems (DHSs) are characterized by a number of advantages with respect to conventional decentralized heating plants [1]. The European Directive 2012/27 [2] calls for the presence of a renewable share inside the so-called "efficient district heating and cooling". Among the renewable energy sources, an increased use of solar energy can be credited to worldwide trends and legislative incentives directed to resolving environmental issues. However, one of the longstanding barriers to solar energy technology lies in the noticeable seasonal misalignment between solar energy supply and thermal energy demand. Long-term storages allow for thermal energy storage over weeks and months, with they being a challenging key technology for solving this timediscrepancy [3-5]. Sensible seasonal heat storage is a comparatively mature technology in which water, rock-sort material and/or ground/soil are frequently used as storage materials [3-5]. There are four main types of sensible seasonal energy storage in operation [3-5]; based on a comprehensive literature review, Rad and Fung [1] concluded that Borehole Thermal Energy Storage (BTES) has the most favorable condition for long-term energy storage thanks to the large amounts of energy involvement and relatively low cost of storage media. BTESs consist of closed-loops where heat is charged or discharged by vertical or horizontal Borehole Heat Exchangers (BHEs), which are installed into boreholes with a depth up to $100 \mathrm{~m}$ below the ground surface. After drilling, a "U" pipe is inserted into the borehole; in order to enhance the thermal contact with the surrounding soil, the borehole is then filled with a high thermal conductivity grouting material. BHEs can be single or double U-pipes; a certain number of BHEs can be hydraulically connected in series to a row and a certain number of rows can be connected in parallel. The socalled Central Solar Heating Plants with Seasonal Storage (CSHPSS), i.e. district heating systems based on the exploitation of solar source and integrated with long-term thermal energy storage, are gaining more and more attention as a very promising alternative to fossil fuel heating [5] and they have been researched by several entities, such as IEA's Task 32 and Task 45 [6, 7], as well as the German programme Solarthermie [8]. Numerous CSHPSS projects have seen the light of day in Europe and North America [5], both on large and small scales. All studies [1, 3-5] came to the conclusion that CSHPSS can play a significant role in the implementation of future smart energy systems, even if future researches are needed [5]. One of the main factors of concern for the design of future CSHPSSs is the energy storage, considering that an oversized system or a system with an insufficient number of boreholes will lead to an increase in costs and losses $[9,10]$. The performance of a BTES is greatly affected by its geometry, thermo-physical properties of both soil and grout, temperature and mass flow rate of heat carrier fluid, etc. Several papers focusing on BHEs deal with the influence of one or more of these parameters, but the literature review reveals that global studies assessing the impact of BTES design on the overall energy, environmental and economic performance of smallscale solar district heating systems are not available. A limited 
number of studies have been performed with reference to solar district heating systems under Italian climatic conditions and the integration of seasonal thermal energy storages has been rarely considered [11-16]. In addition, most of these works performed an energy analysis in terms of solar fraction as well as primary energy savings, without considering the emissions as well as the economic performance. Finally, it should be noticed that districts with a size much larger than that one considered in this study have been analyzed in the abovemotioned works. This justifies the need to perform additional investigations for Italian applications. In this paper, a solar hybrid district heating system is modelled, simulated and analyzed by means of TRNSYS 17 [17] over a 5-year period. The proposed plant is based on the operation of solar thermal collectors connected with both a short-term thermal energy storage (STTES) as well as a seasonal single U-pipe vertical Borehole Thermal Energy Storage (BTES). The system is aimed at satisfying the heating demand and domestic hot water requirements of a micro-scale district composed of 6 Italian typical single-family houses under the climatic conditions of Naples (southern Italy). In a previous study [18], the authors investigated the performance of the proposed plant upon varying the following parameters: (i) area of solar thermal collectors, (ii) volume of STTES, (iii) volume of BTES. In this work the performance of the optimal plant configuration, previously identified by the authors on the basis of the simulation results of a huge parametric analysis [18], are further investigated in more detail upon varying the characteristics of the BTES in terms of (i) thermal conductivity of soil $(0.5,1.5$ and $3.0 \mathrm{~W} / \mathrm{mK})$, (ii) thermal conductivity of grout $(0.5,1.3$ and $5.0 \mathrm{~W} / \mathrm{mK})$, U-pipe spacing $(0.0254$, 0.0350 and $0.0500 \mathrm{~m}$ ), heat carrier fluid typology (mixture of water and ethylene glycol or pure water), number of BHEs (2, 4, 6, 8 and 10 BHEs), type of BHEs connection (series, parallel or mixed). A total of new 67 simulation cases are analyzed in this study. The primary energy consumption, the equivalent $\mathrm{CO}_{2}$ emissions and the operating costs associated to each plant configuration are then compared with those associated to a typical Italian decentralized heating system assumed as reference in order to (i) assess the potential benefits, (ii) explore the influence of BTES configuration on the overall system performance, and (iii) establish some simple rules for the initial phase of BTES design.

\section{DESCRIPTION OF THE DISTRICT}

The district served by the proposed plant is composed of 6 typical Italian single-family residences located in Naples (south of Italy; latitude $=40^{\circ} 51^{\prime} 46^{\prime \prime} 80 \mathrm{~N}$; longitude $=14^{\circ}$ 16' 36" 12 E; Heating Degree-Days = 1,034). Three different typologies of residential buildings (A, B and C) have been considered (with 2 residential buildings for each typology). Table 1 summarizes the main characteristics of the buildings composing the district.

Table 1. Main characteristics of residential buildings

\begin{tabular}{cccc}
\hline & \multicolumn{3}{c}{ Type of buildings } \\
& A & B & C \\
\hline Number of buildings (-) & 2 & 2 & 2 \\
Floor area $\left(\mathbf{m}^{\mathbf{2}}\right)$ & 60 & 78 & 114 \\
Windows' area $\left(^{\mathbf{2}}\right)$ & 84 & 102 & 230 \\
Volume $\left(\mathbf{m}^{\mathbf{3}}\right)$ & 230 & 370 & 448 \\
Maximum number of occupants (-) & 3 & 4 & 5 \\
\hline
\end{tabular}

In order to be compliant with Italian legislation requirements, the thermal transmittance of the buildings' envelopes has been equated to the given threshold values $(2.40$ $\mathrm{W} / \mathrm{m}^{2} \mathrm{~K}$ for windows, $0.36 \mathrm{~W} / \mathrm{m}^{2} \mathrm{~K}$ for roofs, $0.40 \mathrm{~W} / \mathrm{m}^{2} \mathrm{~K}$ for floors, $0.38 \mathrm{~W} / \mathrm{m}^{2} \mathrm{~K}$ for external vertical walls), whatever the building typology is. For each residential building typology, a specific annual stochastic profile (composed of 365 different daily stochastic profiles) at one-minute time resolution has been considered for determining the occupancy as well as the electric demand associated to both lighting and domestic appliances; these annual stochastic profiles have been obtained by using the models developed by Richardson and Thomson [19]. A total annual electric energy demand for the 6 residential buildings of $14.98 \mathrm{MWh} / \mathrm{y}$ has been derived. Several sets of yearly load profiles for the domestic hot water demand have been specified within the IEA-SHC Task 26 [20]. In this study, a demand profile with an average basic load of $100 \mathrm{~L} /$ day in the time scale of one minute has been used for both residential building typologies $\mathrm{A}$ and $\mathrm{B}$, while a demand profile with an average basic load of 200 L/day in the time scale of one minute has used for residential building typology C. The maximum thermal demand for space heating is about $28.2 \mathrm{~kW}$ (typology $\mathrm{C}$ of residential buildings), while the maximum thermal load for DHW production is about $37.5 \mathrm{~kW}$ (typology $\mathrm{C}$ of residential buildings); the maximum electric demand of the residential buildings is about $5.8 \mathrm{~kW}$ (typology $\mathrm{C}$ of residential buildings)

\section{DESCRIPTION OF THE PROPOSED DISTRICT HEATING SYSTEM}

The schematic of the proposed CSHPSS is reported in Figure 1.

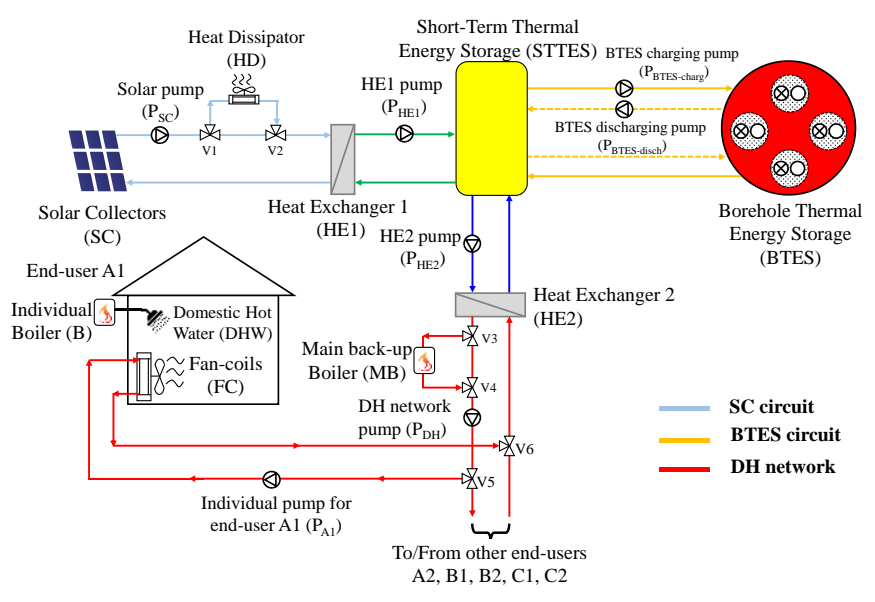

Figure 1. Schematic of the proposed central solar heating plant with seasonal thermal energy storage (CSHPSS)

In this figure, the following main components of the system can be identified: end-users ( 6 residential buildings A1, A2, $\mathrm{B} 1, \mathrm{~B} 2, \mathrm{C} 1, \mathrm{C} 2$ ), solar thermal collectors (SC), heat dissipator (HD), short-term thermal energy storage (STTES), borehole thermal energy storage (BTES) with vertical single U-pipes borehole heat exchangers, main natural gas-fired back-up boiler (MB), heat exchangers (HE1 and HE2), local individual boilers (B) for DHW production, fan-coils (FC), pumps (P), 3 way valves $(\mathrm{V})$ and pipes. The following three main circuits are highlighted: SC circuit, BTES circuit and district heating (DH) network. The solar energy captured by the SCs is first 
transferred, through the HE1, into the STTES; dissipation of solar energy surplus is obtained by blowing air across a finned coil heat exchanger (HD) when the temperature at the outlet of solar field is higher than $95^{\circ} \mathrm{C}$. From the STTES, if there is a heating demand, the solar energy is transferred through the HE2 into the distribution network, and then to the end-users for space heating; every building is equipped with a group of fan-coils, supplied by the STTES. If the solar energy is not immediately required for heating purposes, it can be moved from the STTES to the BTES system during the whole year ("BTES charging mode"): in this case, the heat carrier fluid is taken at the top of STTES, circulated through the BTES and then re-entered at the bottom of the STTES. Only during the heating season, thermal energy stored in the BTES field can return into the STTES ("BTES discharging mode") to eventually integrate the temperature level into the STTES. During the charging mode, the flow direction is from the center to the boundaries of the BTES to obtain higher temperatures in the center and lower ones at the boundaries of the storage; the flow direction is reversed during the discharging phase. A main natural gas-fired boiler (MB) is used to supplement the space heating demand when the solar energy collected and stored in the STTES and BTES cannot meet the energy requirements. An individual natural gas-fired boiler has also been installed inside each residential building specifically devoted to the domestic hot water production. All the electric requirements are satisfied with the electric energy supplied by the central national grid. The main characteristics of each component of the proposed CSHPSS are indicated in Table 2.

\subsection{Simulation models}

In the TRaNsient SYStems (TRNSYS) software platform [17] each physical piece of the thermodynamic equipment is modeled with a component (named "Type" in TRNSYS terminology). TRNSYS Types have been selected from the TRNSYS libraries and enhanced by manufactures performance data or information available in the current scientific literature. The duration of simulation period (5 years) has been defined in order to consider that it takes time to fully charge the seasonal storage. January $1^{\text {st }}$ has been assumed as starting date of the simulations. A simulation time step of 1 minute has been adopted.

Table 2. Main characteristics of CSHPSS components

\begin{tabular}{|c|c|}
\hline \multicolumn{2}{|c|}{ Solar thermal collectors $(\mathbf{S C})[21]$} \\
\hline Collector technology / model & Flat plate / FSK 2.5 \\
\hline $\begin{array}{l}\text { Gross / Aperture area of a single } \\
\text { collector }\left(\mathrm{m}^{2}\right)\end{array}$ & $2.51 / 2.31$ \\
\hline Number of collectors & $\begin{array}{c}24 \text { ( } 8 \text { rows with } 3 \\
\text { series-connected } \\
\text { panels per row) }\end{array}$ \\
\hline Tilted angle / Azimuth / Orientation & $30 \% 0 \%$ South \\
\hline \multicolumn{2}{|c|}{ Short-term thermal energy storage (STTES) [22] } \\
\hline Volume $\left(\mathrm{m}^{3}\right) /$ Height $(\mathrm{m})$ & $6.0 / 3.5$ \\
\hline \multicolumn{2}{|c|}{ Boreholes thermal energy storage system (BTES) } \\
\hline $\begin{array}{l}\text { BTES volume }\left(\mathrm{m}^{3}\right) / \text { Borehole radius } \\
(\mathrm{m})\end{array}$ & $435.8 / 0.15$ \\
\hline Inner / Outer radius of U-pipe (m) & $0.01372 / 0.01664$ \\
\hline Pipe / Gap thermal conductivity (W/mK) & $0.42 / 1.40$ \\
\hline \multicolumn{2}{|c|}{ Main back-up boiler (MB) [23] } \\
\hline Fuel / Rated capacity (kW) & Natural gas / 26.6 \\
\hline
\end{tabular}

Type 56 has been used to model the thermal behavior of the buildings composing the district. The Type 557a [24], adopted to model the BTES, is considered to be the state-of-the-art in dynamic simulation of ground heat exchanger that interacts thermally with the ground and has been used by several researchers for simulating energy systems with BTES. The storage volume has the shape of cylinder with vertical symmetry axis; within this cylindrical storage volume, the ground is considered to be homogeneous. The layout of the borehole field is fixed hexagonally and uniformly within the storage volume in the simulation. The Type 534 used to model the STTES is based on the assumption that the tanks can be divided into fully-mixed equal sub-volumes. In this paper, the STTES has been modeled with 10 isothermal temperature layers to better represent the stratification in the tank, where the top layer is 1 and the bottom layer is 10 . The model has been calibrated based on manufacturer data [22]. Flat-plate solar thermal collectors have been modeled using TRNSYS Type 1b. In this component model, the collector efficiency $\left(\eta_{\mathrm{SC}}\right)$ has been modeled by a second-order equation (Eq. 1), and correction for off-normal solar incidence is applied by a second-order incidence angle modifier (K) equation (Eq. 2):

$$
\begin{gathered}
\eta_{S C}=0.7484-16.17 \cdot\left(T_{i n, S C}-T_{a}\right) / G \\
K=1-0.103 \cdot S
\end{gathered}
$$

where, $T_{i n, S C}$ is fluid inlet temperature, $T_{a}$ is ambient temperature, $G$ is solar radiation and $S=1 / \cos \theta-1$ ( $\theta$ is the incident angle for beam radiation). The coefficients (in SI units) listed in Eqs. 1-2 have been based on manufacturer data for a single flat-plate collector [21]. The counter flow plate heat exchangers HE1 and HE2 have been modeled with the TRNSYS Type $5 b$ by assuming an overall heat transfer coefficient equal to $25 \mathrm{~W} / \mathrm{K}$ per GJ of the heat demand for HE1 and $54.3 \mathrm{~W} / \mathrm{K}$ per $\mathrm{m}^{2}$ of collector areas for HE2, respectively, according to the values suggested by Pahud [25]. The main boiler has been modeled by TRNSYS Type 700; a rated capacity of $26.6 \mathrm{~kW}$ has been assumed. The MB is able to modulate the thermal output between $40 \%$ and $100 \%$ of its rated capacity, with an efficiency varying upon varying the thermal output $P_{t h, o u t, M B}$ according to the following equation (based on manufacturer performance data [23]):

$$
\eta_{M B}=0.0015 \cdot P_{\text {th,out }, M B}+0.8814
$$

Individual boilers installed inside the houses for DHW production have been modeled through TRNSYS Type 700 by assuming a rated capacity of $26.6 \mathrm{~kW}$ per each, with a constant efficiency equal to $90 \%$. Fan-coils have been modeled by TRNSYS type 753d. It has been calibrated based on manufacturer performance data. The heat dissipator is simulated by considering TRNSYS Type 511, that models a device used to cool a liquid stream by blowing air across coils containing the liquid. A distribution network with a single pair of supply and return pipes has been used for both the distribution network as well as the solar field collector circuit. TRNSYS type 31 has been used to model the pipes and calculate the related heat losses by assuming a loss coefficient equal to $0.05 \mathrm{~kJ} / \mathrm{hm}^{2} \mathrm{~K}$. The DH network pump has been modeled by TRNSYS Type 742, while all the other pumps in the system have been modeled by TRNSYS Type 656. A 
specific EnergyPlus weather data file [26] has been considered for modeling the weather conditions of Naples; the weather data are one-year long and, therefore, have to be the same each year.

\subsection{Control logics}

The duration of the heating period has been assumed from $15^{\text {th }}$ November up to $31^{\text {st }}$ March. The heat carrier fluid flows through the fan-coils only in cases when there is a call for heat triggered by a thermostat installed in each building. The room temperature is targeted to be kept at $20{ }^{\circ} \mathrm{C}$ only in the case of at least one occupant being inside the building, otherwise the indoor air temperature is not controlled. When the room temperature is lower than $19.5^{\circ} \mathrm{C}$, it calls for heat from the STTES; the call for heat signal will be disabled when the room temperature reaches $20.5^{\circ} \mathrm{C}$. The set-point for the $\mathrm{DH}$ supply temperature is $55^{\circ} \mathrm{C}$, so that the target of the main back-up boiler thermostat is fixed at $55^{\circ} \mathrm{C}$ with a dead band of $5{ }^{\circ} \mathrm{C}$. The DH network pump operates continuously with a flow rate varying between $497.7 \mathrm{~kg} / \mathrm{h}$ and $3,782.7 \mathrm{~kg} / \mathrm{h}$ (depending on the number of buildings requiring thermal energy for space heating) during the heating season. Even if there is no heat demand, the DH network pump operates with the minimum flow rate to avoid a significant temperature drop in the district heating network; the flow rate on the source side of the heat exchanger HE2 is set to the same value of the load side. The solar energy recovery is based on the comparison between the current values of the temperature at node 10 (lower part) of the STTES and the temperature of the fluid exiting the solar field. The BTES charging/discharging is controlled based on the current values of the temperature at nodes 1 (upper part) and 10 (lower part) of the STTES, the temperature in the center of BTES field as well as the room target temperature $\left(20^{\circ} \mathrm{C}\right)$. In more detail, during the BTES charging mode, the flow rate, which is constant, is set to half of the nominal flow rate in the collector array; in the BTES discharging mode, the flow rate is set to the current value used in the distribution network. The DHW is assumed to be produced at $45^{\circ} \mathrm{C}$. Table 3 reports the control strategies for activating/deactivating the main components of the proposed CSHPSS.

\section{DESCRIPTION OF THE REFERENCE HEATING SYSTEM}

A conventional Italian decentralized heating system (CS) has been modeled and simulated to be compared with the proposed CSHPSS while serving the same district composed of 6 residential buildings (Table 1). In the reference heating system, each building is equipped only with a natural gas-fired boiler (characterized by a constant thermal efficiency of $90 \%$ with a rated capacity of $26.6 \mathrm{~kW}$ ) used for both space heating purposes (through a group of fan-coils installed inside the buildings) and domestic hot water production. The heat carrier fluid flows through the fan-coils only in cases when there is a call for heat triggered by a thermostat installed in each building. The room temperature is targeted to be kept at $20^{\circ} \mathrm{C}$ (with a dead band of $1{ }^{\circ} \mathrm{C}$ ) only in the case of at least one occupant being inside the building, otherwise, the indoor air temperature is not controlled (as in the proposed CSHPSS). The set-point of the individual boilers is $55{ }^{\circ} \mathrm{C}$ for heating purposes, with a dead band of $5{ }^{\circ} \mathrm{C}$. The occupancy, electric and DHW demand profiles used for the proposed CSHPSS have been also assumed for the residential buildings served by the reference heating system. As in the proposed CSHPSS, the DHW is assumed to be produced at $45{ }^{\circ} \mathrm{C}$. All the electric requirements are satisfied with the electric energy supplied by the central national grid (as in the proposed CSHPSS).

Table 3. Control strategies of proposed CSHPSS

\begin{tabular}{|c|c|c|}
\hline & ON & OFF \\
\hline $\begin{array}{l}\text { Solar pump } \\
\& \text { HE1 pump }\end{array}$ & $\begin{array}{c}\left(\mathrm{T}_{\mathrm{SC}, \text { out }}-\mathrm{T}_{10, \mathrm{STTES}}\right) \geq 10^{\circ} \mathrm{C} \\
\text { AND } \\
\mathrm{T}_{1, \mathrm{STTES}} \leq 90^{\circ} \mathrm{C}\end{array}$ & $\begin{array}{c}\left(\mathrm{T}_{\mathrm{SC}, \text { out }}-\mathrm{T}_{10, \mathrm{STTES}}\right) \leq \\
2{ }^{\circ} \mathrm{C} \text { OR } \\
\mathrm{T}_{1, \mathrm{STTES}}>90{ }^{\circ} \mathrm{C}\end{array}$ \\
\hline \multirow{5}{*}{$\begin{array}{l}\text { BTES pumps } \\
\text { (charging and } \\
\text { discharging) }\end{array}$} & $\begin{array}{c}\text { CHARGING MODE } \\
\text { Heating period: } \\
\text { (T10,STTES - Troom,set-point }) \geq \\
10{ }^{\circ} \mathrm{C} \text { AND } \mathrm{T}_{1, \text { STTES }} \geq \\
60{ }^{\circ} \mathrm{C} \text { AND }\left(\mathrm{T}_{1, \mathrm{STTES}}-\right. \\
\left.\mathrm{T}_{\mathrm{BTES}, \text { center }}\right) \geq 10^{\circ} \mathrm{C}\end{array}$ & $\begin{array}{c}\text { CHARGING MODE } \\
\text { Heating period: } \\
\left(\mathrm{T}_{10, \text { STTES }}-\mathrm{T}_{\text {room,set- }}\right. \\
\text { point }) \leq 2{ }^{\circ} \mathrm{C} \mathrm{OR} \\
\mathrm{T}_{1, \text { STTES }} \leq 55^{\circ} \mathrm{C} \text { OR } \\
\left(\mathrm{T}_{1, \text { STTES }}-\mathrm{T}_{\mathrm{BTES} \text {, center }}\right) \\
\leq 2{ }^{\circ} \mathrm{C}\end{array}$ \\
\hline & $\begin{array}{c}\frac{\text { Cooling period: }}{\left(\mathrm{T}_{1, \mathrm{STTES}}-\mathrm{T}_{\mathrm{BTES}, \text { center }}\right) \geq} \\
10^{\circ} \mathrm{C}\end{array}$ & $\begin{array}{l}\frac{\text { Cooling period: }}{\left(\mathrm{T}_{1, \mathrm{STTES}}-\mathrm{T}_{\mathrm{BTES}, \mathrm{center}}\right)} \\
\quad \leq 2^{\circ} \mathrm{C}\end{array}$ \\
\hline & $\begin{array}{c}\text { DISCHARGING MODE } \\
\text { Heating period: }\end{array}$ & $\begin{array}{c}\text { DISCHARGING } \\
\text { MODE }\end{array}$ \\
\hline & & \\
\hline & $\mathrm{T}_{1, \mathrm{STTES}} \leq 60^{\circ} \mathrm{C}$ & $\begin{array}{c}\leq 2{ }^{\circ} \mathrm{C} \mathrm{OR} \\
\mathrm{T}_{1, \text { STTES }}>65^{\circ} \mathrm{C}\end{array}$ \\
\hline $\begin{array}{l}\text { DH network } \\
\text { pump }\end{array}$ & Heating period & Cooling period \\
\hline $\begin{array}{l}\text { Individual } \\
\text { pumps \& Fan- } \\
\text { coils }\end{array}$ & $\begin{array}{l}\text { Heating period AND } \\
\text { Troom }<19.5^{\circ} \mathrm{C}\end{array}$ & $\begin{array}{c}\text { Cooling period OR } \\
\mathrm{T}_{\text {room }}>20.5^{\circ} \mathrm{C}\end{array}$ \\
\hline HE2 pump & $\begin{array}{c}\text { Heating period AND } \\
\text { DH network pump ON } \\
\text { AND } \\
\left(\mathrm{T}_{\text {in,HE2,hot }}-\mathrm{T}_{\text {in,HE2,cold })} \geq\right. \\
5^{\circ} \mathrm{C}\end{array}$ & $\begin{array}{c}\text { Cooling period OR } \\
\text { DH network pump } \\
\text { OFF OR } \\
\text { ( } \mathrm{T}_{\left.\text {in,HE2,hot }-\mathrm{T}_{\text {in,HE2,cold }}\right)} \leq 2{ }^{\circ} \mathrm{C}\end{array}$ \\
\hline Main boiler & $\begin{array}{c}\text { Heating period AND } \\
\dot{\mathrm{m}}_{\mathrm{FC}}>0 \mathrm{AND} \\
\mathrm{T}_{\mathrm{in}, \mathrm{MB}}<50^{\circ} \mathrm{C}\end{array}$ & $\begin{array}{c}\text { Cooling period OR } \\
\dot{\mathrm{m}}_{\mathrm{FC}}=0 \mathrm{OR} \\
\mathrm{T}_{\text {out }, \mathrm{MB}} \leq 55^{\circ} \mathrm{C}\end{array}$ \\
\hline $\begin{array}{l}\text { Individual } \\
\text { boilers for } \\
\text { DHW } \\
\text { production }\end{array}$ & $\begin{array}{c}\dot{\mathrm{m}}_{\mathrm{DHW}}>0 \text { AND } \\
\mathrm{T}_{\mathrm{in}, \mathrm{B}}<45^{\circ} \mathrm{C}\end{array}$ & $\begin{array}{c}\dot{\mathrm{m}}_{\mathrm{DHW}}=0 \text { AND } \\
\mathrm{T}_{\mathrm{out}, \mathrm{B}} \leq 45^{\circ} \mathrm{C}\end{array}$ \\
\hline
\end{tabular}

\section{METHODS OF ANALYSIS}

The total aperture area of solar collectors $\left(55.4 \mathrm{~m}^{2}\right)$, the volume of STTES $\left(6.0 \mathrm{~m}^{3}\right)$ as well as the volume of BTES $\left(435.8 \mathrm{~m}^{3}\right)$ have been determined by the authors based on the results of a huge sensitivity analysis performed in a previous study [18] where the following parameters have been varied:

$$
\mathrm{SCA}=\frac{\text { Gross solar collectors area }}{\text { Annual space heating demand }}
$$


SSV $=\frac{\text { Short-term thermal energy storage volume }}{\text { Annual space heating demand }}$

$$
\text { SLV }=\frac{\text { Long-term thermal energy storage volume }}{\text { Gross solar collectors area }}
$$

In particular, 3 different values of SCA $(2.21,3.32,4.42$ $\left.\mathrm{m}^{2} / \mathrm{MWh}\right)$, SSV $\left(0.2,0.4,0.7 \mathrm{~m}^{3} / \mathrm{MWh}\right)$ and $\operatorname{SLV}(1.8,3.6,7.2$ $\mathrm{m}^{3} / \mathrm{m}^{2}$ ) have been analyzed by the authors in [18] by simulating 27 plant configurations; the variation ranges of SCA, SSV and SLV have been defined based on the design guidelines suggested by Pahud [25] as well as according to the characteristics of commercial products available on the market [18]. The simulation results associated to the configurations corresponding to the above-mentioned values of SCA, SSV and SLV have been compared with those associated to a conventional heating system in terms of primary energy, $\mathrm{CO}_{2}$ equivalent emissions and operating costs. The comparison highlighted that the best case in terms of primary energy saving is the case characterized by SCA $=4.42 \mathrm{~m}^{2} / \mathrm{MWh}, \mathrm{SSV}=0.4$ $\mathrm{m}^{3} / \mathrm{MWh}$ and SLV $=7.2 \mathrm{~m}^{3} / \mathrm{m}^{2}$, with a total of 4 BHEs (two boreholes connected in series to a row and two rows connected in parallel) characterized by a depth of $24.9 \mathrm{~m}$.

Taking into account that the borehole thermal energy storage is a key component for optimizing the overall performance of the solar district heating system, in this paper additional 54 configurations have been investigated by varying the following parameters: (i) thermal conductivity of soil $\lambda_{\text {soil }}(0.5 \mathrm{~W} / \mathrm{mK}, 1.5$ $\mathrm{W} / \mathrm{mK}, 3.0 \mathrm{~W} / \mathrm{mK})$; (ii) thermal conductivity of grout $\lambda_{\text {grout }}(0.5$ $\mathrm{W} / \mathrm{mK}, 1.3 \mathrm{~W} / \mathrm{mK}, 5.0 \mathrm{~W} / \mathrm{mK})$; (iii) U-pipe spacing $(0.0254 \mathrm{~m}$, $0.0350 \mathrm{~m}, 0.0500 \mathrm{~m}$ ); (iv) heat carrier fluid (mixture of water and ethylene glycol ( $60 \% / 40 \%$ by volume) or pure water). The variation ranges of thermal conductivity of soil, thermal conductivity of grout and U-pipe spacing are defined based on information available in the current literature [27]; in particular, in [27] it is stated that the values of $\lambda$ for the grouting material can vary between 0.5 and $5.0 \mathrm{~W} / \mathrm{mK}$, while the thermal conductivity of soil is in the range $0.5 \div 3.0 \mathrm{~W} / \mathrm{mK}$. Table 4 describes the corresponding 54 simulation cases analyzed in this study and characterized by $\mathrm{SCA}=4.42$ $\mathrm{m}^{2} / \mathrm{MWh}, \mathrm{SSV}=0.4 \mathrm{~m}^{3} / \mathrm{MWh}$ and $\mathrm{SLV}=7.2 \mathrm{~m}^{3} / \mathrm{m}^{2}$, with a total of 4 BHEs (two boreholes connected in series to a row and two rows connected in parallel) characterized by a depth of $24.9 \mathrm{~m}$.

The energy, environmental and economic analysis of the 54 configurations described in Table 4 allowed to identify the simulation case 27 as that one characterized by the best performance in the case of the mixture of water and ethylene glycol is used. Starting from this configuration, additional simulations have been carried out in this paper in order to analyze the impacts of both (a) the number of BHEs (2, 4, 6, 8, 10 BHEs have been considered) as well as (b) the BHEs connection (series-connected, parallel-connected, mixed connection). In more detail, the plant configurations described in Table 5 have also been simulated and analyzed; they are characterized by the same following design parameters: SCA $=4.42 \mathrm{~m}^{2} / \mathrm{MWh}, \mathrm{SSV}=0.4 \mathrm{~m}^{3} / \mathrm{MWh}, \mathrm{SLV}=7.2 \mathrm{~m}^{3} / \mathrm{m}^{2}$, thermal conductivity of soil $=3.0 \mathrm{~W} / \mathrm{mK}$, thermal conductivity grout $=5.0 \mathrm{~W} / \mathrm{mK}$, U-pipe spacing $=0.0500 \mathrm{~m}$, and heat carrier fluid (mixture of mixture of water and ethylene glycol).

In the next sections the methods of energy, environmental and economic analyses used in this study are detailed.
Table 4. Matrix of 54 simulation cases upon varying the thermal conductivity of soil and grout, U-pipe spacing and heat carrier fluid ( 2 parallel-connected BHEs +2 seriesconnected BHEs with a depth of $24.9 \mathrm{~m}$ )

\begin{tabular}{|c|c|c|c|c|}
\hline $\begin{array}{c}\text { Simulation } \\
\text { cases }\end{array}$ & $\begin{array}{c}\lambda_{\text {soil }} \\
(W / m K)\end{array}$ & $\begin{array}{c}\lambda_{\text {grout }} \\
(\mathrm{W} / \mathbf{m K})\end{array}$ & $\begin{array}{c}\text { U-pipe } \\
\text { spacing } \\
(\mathrm{m})\end{array}$ & $\begin{array}{c}\text { Heat } \\
\text { carrier } \\
\text { fluid }\end{array}$ \\
\hline 1 & 0.50 & \multirow{3}{*}{0.50} & \multirow{9}{*}{0.0254} & \multirow{27}{*}{$\begin{array}{c}\text { mixture } \\
\text { of water } \\
\text { and } \\
\text { ethylene } \\
\text { glycol } \\
(60 \% / 40 \\
\% \text { by } \\
\text { volume })\end{array}$} \\
\hline 2 & 1.50 & & & \\
\hline 3 & 3.00 & & & \\
\hline 4 & 0.50 & \multirow{3}{*}{1.30} & & \\
\hline 5 & 1.50 & & & \\
\hline 6 & 3.00 & & & \\
\hline 7 & 0.50 & \multirow{3}{*}{5.00} & & \\
\hline 8 & 1.50 & & & \\
\hline 9 & 3.00 & & & \\
\hline 10 & 0.50 & \multirow{3}{*}{0.50} & \multirow{9}{*}{0.0350} & \\
\hline 11 & 1.50 & & & \\
\hline 12 & 3.00 & & & \\
\hline 13 & 0.50 & \multirow{3}{*}{1.30} & & \\
\hline 14 & 1.50 & & & \\
\hline 15 & 3.00 & & & \\
\hline 16 & 0.50 & \multirow{3}{*}{5.00} & & \\
\hline 17 & 1.50 & & & \\
\hline 18 & 3.00 & & & \\
\hline 19 & 0.50 & \multirow{3}{*}{0.50} & \multirow{9}{*}{0.0500} & \\
\hline 20 & 1.50 & & & \\
\hline 21 & 3.00 & & & \\
\hline 22 & 0.50 & \multirow{3}{*}{1.30} & & \\
\hline 23 & 1.50 & & & \\
\hline 24 & 3.00 & & & \\
\hline 25 & 0.50 & \multirow{3}{*}{5.00} & & \\
\hline 26 & 1.50 & & & \\
\hline 27 & 3.00 & & & \\
\hline 28 & 0.50 & \multirow{3}{*}{0.50} & \multirow{9}{*}{0.0254} & \\
\hline 29 & 1.50 & & & \\
\hline 30 & 3.00 & & & \\
\hline 31 & 0.50 & \multirow{3}{*}{1.30} & & \\
\hline 32 & 1.50 & & & \\
\hline 33 & 3.00 & & & \\
\hline 34 & 0.50 & \multirow{3}{*}{5.00} & & \\
\hline 35 & 1.50 & & & \\
\hline 36 & 3.00 & & & \\
\hline 37 & 0.50 & \multirow{3}{*}{0.50} & \multirow{9}{*}{0.0350} & \\
\hline 38 & 1.50 & & & \\
\hline 39 & 3.00 & & & \\
\hline 40 & 0.50 & & & \\
\hline 41 & 1.50 & 1.30 & & pure \\
\hline 42 & 3.00 & & & \\
\hline 43 & 0.50 & & & \\
\hline 44 & 1.50 & 5.00 & & \\
\hline 45 & 3.00 & & & \\
\hline 46 & 0.50 & & & \\
\hline 47 & 1.50 & 0.50 & & \\
\hline 48 & 3.00 & & & \\
\hline 49 & 0.50 & & & \\
\hline 50 & 1.50 & 1.30 & 0.0500 & \\
\hline 51 & 3.00 & & & \\
\hline 52 & 0.50 & & & \\
\hline 53 & 1.50 & 5.00 & & \\
\hline 54 & 3.00 & & & \\
\hline
\end{tabular}


Table 5. Matrix of 14 simulation cases upon varying the number of BHEs and BHEs connection $\left(\lambda_{\text {soil }}=3.0 \mathrm{~W} / \mathrm{mK}\right.$, $\lambda_{\text {grout }}=5.0 \mathrm{~W} / \mathrm{mK}, \mathrm{U}$-pipe spacing $=0.0500 \mathrm{~m}$, mixture of water and ethylene glycol)

\begin{tabular}{|c|c|c|c|}
\hline $\begin{array}{l}\text { Simulation } \\
\text { cases }\end{array}$ & $\begin{array}{c}\text { Number of BHEs and } \\
\text { BHEs connection } \\
(-)\end{array}$ & $\begin{array}{l}\text { Depth of } \\
\text { boreholes } \\
\text { (m) }\end{array}$ & $\begin{array}{l}\text { BTES } \\
\operatorname{radius}(\mathbf{m})\end{array}$ \\
\hline 55 & 2 parallel-connected BHEs & 49.73 & 1.67 \\
\hline 56 & 2 series-connected BHEs & 49.73 & 1.67 \\
\hline 57 & 4 parallel-connected BHEs & 24.87 & 2.36 \\
\hline 58 & 4 series-connected BHEs & 24.87 & 2.36 \\
\hline 27 & $\begin{array}{l}2 \text { parallel-connected }+2 \\
\text { series-connected BHEs }\end{array}$ & 24.87 & 2.36 \\
\hline 59 & 6 parallel-connected BHEs & 16.58 & 2.89 \\
\hline 60 & 6 series-connected BHEs & 16.58 & 2.89 \\
\hline 61 & $\begin{array}{l}3 \text { parallel-connected }+3 \\
\text { series-connected BHEs }\end{array}$ & 16.58 & 2.89 \\
\hline 62 & 8 parallel-connected BHEs & 12.43 & 3.34 \\
\hline 63 & 8 series-connected BHEs & 12.43 & 3.34 \\
\hline 64 & $\begin{array}{l}4 \text { parallel-connected }+4 \\
\text { series-connected BHEs }\end{array}$ & 12.43 & 3.34 \\
\hline 65 & $\begin{array}{l}10 \text { parallel-connected } \\
\text { BHEs }\end{array}$ & 9.95 & 3.73 \\
\hline 66 & 10 series-connected BHEs & 9.95 & 3.73 \\
\hline 67 & $\begin{array}{c}5 \text { parallel-connected }+5 \\
\text { series-connected BHEs }\end{array}$ & 9.95 & 3.73 \\
\hline
\end{tabular}

\subsection{Energy analysis}

The energy comparison between the proposed and conventional systems has been performed in terms of primary energy consumption by means of the index named Primary Energy Saving (PES) defined by Angrisani et al. [28]:

$$
\mathrm{PES}=\left(\mathrm{E}_{\mathrm{p}}^{\mathrm{CS}}-\mathrm{E}_{\mathrm{p}}^{\mathrm{CSHPSS}}\right) / \mathrm{E}_{\mathrm{p}}^{\mathrm{CS}}
$$

where, $E_{p}^{\text {CSHPSS }}$ is the primary energy consumption of the proposed system and $E_{p}^{\mathrm{CS}}$ is the primary energy consumption of the conventional system. The values of $E_{p}^{\mathrm{CSHPSS}}$ and $E_{p}^{\mathrm{CS}}$ of Eq. 7 have been calculated based on the simulation results according to the following formulas:

$$
\begin{aligned}
& \mathrm{E}_{\mathrm{p}}^{\mathrm{CSHPSS}}=\mathrm{E}_{\text {th,MB }}^{\text {CSHPSS }} / \eta_{\mathrm{MB}}+\mathrm{E}_{\mathrm{th}, \mathrm{DHW}}^{\text {CSHPSS }} / \eta_{\mathrm{B}}+ \\
& +\left(\mathrm{E}_{\text {el,plant }}^{\text {CSHPSS }}+\mathrm{E}_{\text {el,buildings }}^{\text {CSHPSS }}\right) / \eta_{\mathrm{PP}} \\
& \mathrm{E}_{\mathrm{p}}^{\mathrm{CS}}=\left(\mathrm{E}_{\mathrm{th}, \text { Heating }}^{\mathrm{CS}}+\mathrm{E}_{\mathrm{th}, \mathrm{DHW}}^{\mathrm{CS}}\right) / \eta_{\mathrm{B}}+ \\
& +\mathrm{E}_{\mathrm{el}, \text { buildings }}^{\mathrm{CS}} / \eta_{\mathrm{PP}}
\end{aligned}
$$

where, $E_{\mathrm{th}, \mathrm{MB}}^{\mathrm{CSHPSS}}$ is the thermal energy produced by the main back-up boiler for space heating purposes in the proposed system, $E_{\mathrm{th}, \mathrm{DHW}}^{\mathrm{CSHPS}}$ and $E_{\mathrm{th}, \mathrm{DHW}}^{\mathrm{CS}}$ represent the thermal energy supplied by the individual boilers for DHW production in the proposed and conventional systems, respectively, $E_{\text {th,Heating }}^{\mathrm{CS}}$ the thermal energy required for heating purposes in the conventional system, $E_{\text {el,plant }}^{\text {CSHPSS }}$ represents the electric energy consumption associated to all pumps and the heat dissipator of the plant in the proposed system, $E_{\text {el,buildings }}^{\text {CSHPS }}$ and $E_{\text {el,buildings }}^{\mathrm{CS}}$ represent the electric energy demands of buildings (due to lighting systems, domestic appliances, fan-coils and individual pumps) associated to the proposed and conventional system, respectively, $\eta_{M B}$ is the efficiency of the main back-up boiler (Eq. 3), $\eta_{B}$ is the efficiency of the individual boilers (assumed constant and equal to $90 \%), \eta_{\mathrm{PP}}$ is the power plant average efficiency in Italy, including transmission losses (assumed equal to $0.42[28]$ ).

\subsection{Emissions analysis}

The assessment of emissions has been performed in this study through the energy output-based emission factor approach suggested by Chicco and Mancarella [29]. In particular, the global carbon dioxide equivalent emissions associated to the operation of the systems have been compared by means of the following indicator $\Delta \mathrm{CO}_{2}[28]$ :

$$
\Delta \mathrm{CO}_{2}=\left(\mathrm{m}_{\mathrm{CO}_{2}}^{\mathrm{CS}}-\mathrm{m}_{\mathrm{CO}_{2}}^{\mathrm{CSHPSS}}\right) / \mathrm{m}_{\mathrm{CO}_{2}}^{\mathrm{CS}}
$$

where, $m_{\mathrm{CO}_{2}}^{\mathrm{CSHSSS}}$ is the mass of global equivalent carbon dioxide emitted by the proposed system and $m_{\mathrm{CO}_{2}}^{\mathrm{CS}}$ is the mass of global equivalent carbon dioxide emitted by the conventional system. The values of $m_{\mathrm{CO}_{2}}^{\mathrm{CSHPSS}}$ and $m_{\mathrm{CO}_{2}}^{\mathrm{CS}}$ of Eq. 10 have been computed as suggested by Chicco and Mancarella [29]:

$$
\begin{aligned}
& \mathrm{m}_{\mathrm{CO}_{2}}^{\mathrm{CSHPSS}}=\beta \cdot\left(\mathrm{E}_{\mathrm{th}, \mathrm{MB}}^{\mathrm{CSHPSS}} / \eta_{\mathrm{MB}}+\mathrm{E}_{\mathrm{th}, \mathrm{DHW}}^{\mathrm{CSHPS}} / \eta_{\mathrm{B}}\right)+ \\
& +\alpha \cdot\left(\mathrm{E}_{\text {el,plant }}^{\mathrm{CSHPSS}}+\mathrm{E}_{\text {el, buildings }}^{\mathrm{CSHPSS}}\right) \\
& \mathrm{m}_{\mathrm{CO}_{2}}^{\mathrm{CS}}=\beta \cdot\left(\mathrm{E}_{\text {th,Heating }}^{\mathrm{CS}}+\mathrm{E}_{\mathrm{th}, \mathrm{DHW}}^{\mathrm{CS}}\right) / \eta_{\mathrm{B}}+ \\
& +\alpha \cdot \mathrm{E}_{\mathrm{el}, \text { buildings }}^{\mathrm{CS}}
\end{aligned}
$$

where, $\alpha$ is the $\mathrm{CO}_{2}$ equivalent emission factor for electricity production, $\beta$ represents the $\mathrm{CO}_{2}$ equivalent emission factor associated to the consumption of natural gas. According to the values suggested in [28] for the Italian scenario, $\alpha$ has been assumed equal to $573 \mathrm{gCO}_{2} / \mathrm{kWh}_{\mathrm{el}}$ and $\beta$ has been considered of $207 \mathrm{gCO}_{2} / \mathrm{kWh}_{\mathrm{p}}$ in this study.

\subsection{Economic analysis}

The economic analysis has been performed by comparing the operating costs of the proposed system with those associated to the reference heating system by means of the following parameter $\triangle \mathrm{OC}$ suggested by Angrisani et al. [28]:

$$
\Delta \mathrm{OC}=\left(\mathrm{OC}^{\mathrm{CS}}-\mathrm{OC}^{\mathrm{CSHPSS}}\right) / \mathrm{OC}^{\mathrm{CS}}
$$

where, $O C^{C S H P S S}$ represents the operating costs of the proposed system and $O C^{C S}$ represents the operating costs of the conventional system. The values of $O C^{C S}$ and $O C^{C S H P S S}$ of Eq. 13 have been calculated as follows: 


$$
\begin{gathered}
\mathrm{OC}^{\mathrm{CS}}=\mathrm{UC}_{\mathrm{ng}} \cdot \frac{\mathrm{E}_{\mathrm{th}, \mathrm{Heating}}^{\mathrm{CS}}+\mathrm{E}_{\mathrm{th}, \mathrm{DHW}}^{\mathrm{CS}}}{\mathrm{LHV}_{\mathrm{ng}} \cdot \rho_{\mathrm{ng}} \cdot \eta_{\mathrm{B}}}+ \\
+\mathrm{UC}_{\mathrm{el}} \cdot \mathrm{E}_{\mathrm{el}, \text { buildings }}^{\mathrm{CS}} \\
\mathrm{OC}^{\mathrm{CSHPSS}}=\mathrm{UC}_{\mathrm{ng}} \cdot \frac{\mathrm{E}_{\mathrm{th}, \mathrm{MB}}^{\mathrm{CSHPS}}}{\mathrm{LHV}_{\mathrm{ng}} \cdot \rho_{\mathrm{ng}} \cdot \eta_{\mathrm{MB}}}+ \\
+\mathrm{UC}_{\mathrm{el}} \cdot\left(\mathrm{E}_{\mathrm{el} \text {,plant }}^{\mathrm{CSHPSS}}+\mathrm{E}_{\mathrm{el}, \text { buildings }}^{\mathrm{CSHPSS}}\right)+\mathrm{UC}_{\mathrm{ng}} \cdot \frac{\mathrm{E}_{\mathrm{th}, \mathrm{DHW}}^{\mathrm{CSHPSS}}}{\mathrm{LHV}_{\mathrm{ng}} \cdot \rho_{\mathrm{ng}} \cdot \eta_{\mathrm{B}}}
\end{gathered}
$$

where, $U C_{n g}$ is the unit cost of natural gas [30], $L H V_{n g}$ is the lower heating value of natural gas (assumed equal to 49,599 $\mathrm{kJ} / \mathrm{kg}$ ), $\rho_{n g}$ is the density of natural gas (assumed equal to 0.72 $\left.\mathrm{kg} / \mathrm{m}^{3}\right), U C_{e l}$ is the unit cost of electric energy purchased from the national central grid [30]. The tariffs of both electric energy as well as natural gas have been kept up-to-date according to the Italian scenario [30]. In particular, the values of $U C_{e l}$ range from $0.121 € / \mathrm{kWh}$ to $0.301 € / \mathrm{kWh}$ [30], while the values of $U C_{n g}$ are the range between $0.466 € / \mathrm{Sm}^{3}$ and $0.848 € / \mathrm{Sm}^{3}[30]$ in Naples.

\section{RESULTS AND DISCUSSION}

In this section, the results associated to the simulation cases 1-67 described in Tables 4 and 5 are discussed and compared with those associated to the operation of the conventional heating system assumed as reference. The annual values of the primary energy consumption, the carbon dioxide equivalent emissions and the operating costs associated to the reference heating system are $60.69 \mathrm{MWh}, 13.76 \mathrm{MgCO}_{2}$ and $4.65 \mathrm{k} €$, respectively. The performance of the CSHPSS varies year by year due to the presence and operation of the thermal energy storages. Figure 2 reports the values of PES (Eq. 7), $\Delta \mathrm{CO}_{2}$ (Eq 10) and $\triangle \mathrm{OC}$ (Eq. 13) as a function of the simulation year for the case 5 . This figure highlights that the performances significantly improve from the $1^{\text {st }}$ to the $3^{\text {rd }}$ year of operation and then become substantially constant; this is thanks to the fact that the temperature in the BTES field mainly increase from the first to second year of operation, allowing for a more effective exploitation of solar energy; with respect to this last point, Figure 3 reports the temperature in the center of BTES field as a function of the time during 5 years for the simulation case 5 .

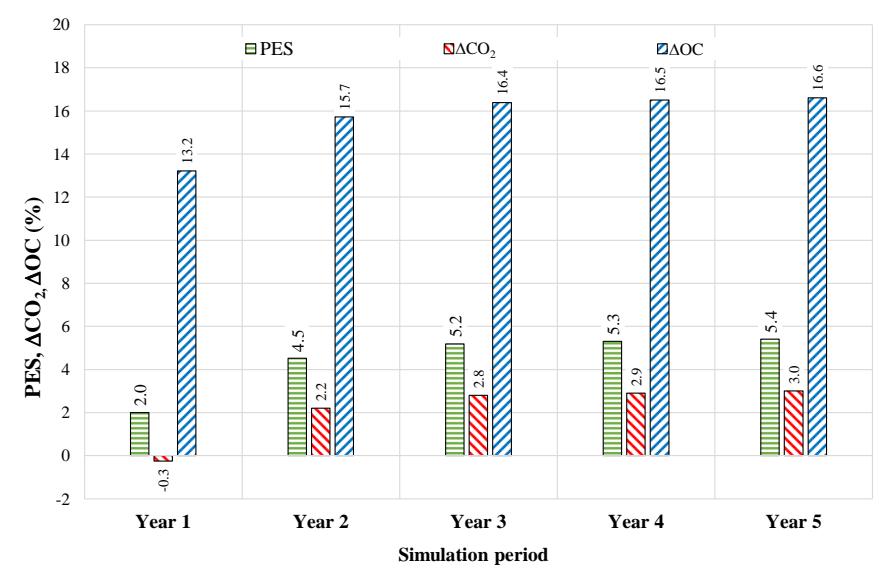

Figure 2. Values of PES, $\Delta \mathrm{CO}_{2}$ and $\triangle \mathrm{OC}$ as a function of the year of operation for the simulation case 5

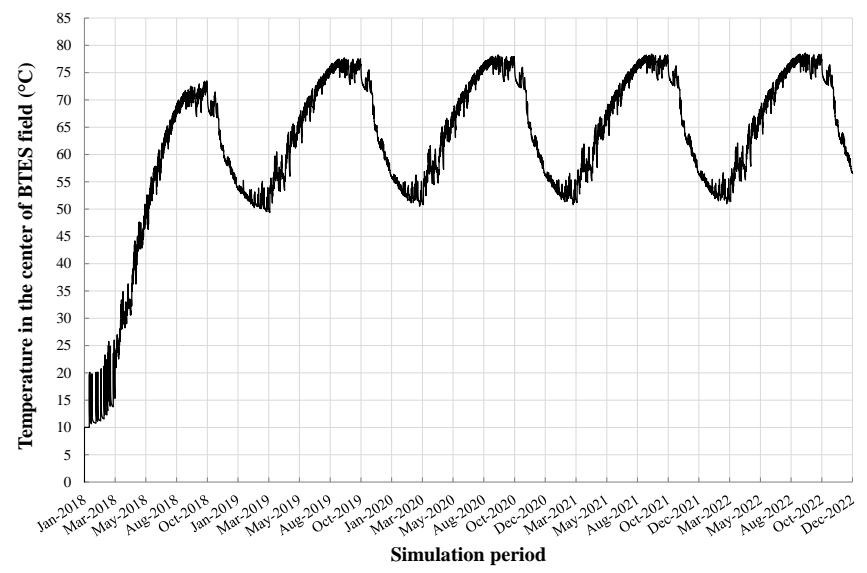

Figure 3. Temperature in the center of BTES as a function the time for the simulation case 5

Similar trends have been obtained for the other simulation cases, so that it can be stated that the behavior of the BTES becomes substantially stable after about two years (whatever the BTES configuration is). In the section 6.1 the effects of (i) thermal conductivity of soil, (ii) thermal conductivity of grout, (iii) U-pipe spacing and (iv) heat carrier fluid on the overall system performance are analyzed, while the impacts associated to both (i) the number of BHEs as well as (ii) the type of BHEs connection are described in the section 6.2.

\subsection{Effects of thermo-physical properties of BTES}

Figures $4 \mathrm{a}, 4 \mathrm{~b}, 4 \mathrm{c}$ show the results associated to the simulation cases 1-54 (see Table 4), reporting the values of PES ${ }^{\text {th-year }}$, $\Delta \mathrm{CO}_{2}{ }^{\text {5th-year }}$ and $\Delta \mathrm{OC}^{\text {5th-year }}$, respectively, referred to the $5^{\text {th }}$ year of simulation as a function of thermal conductivity of soil $(0.5$, 1.5 and $3.0 \mathrm{~W} / \mathrm{mK})$, thermal conductivity of grout $(0.5,1.3$ and $5.0 \mathrm{~W} / \mathrm{mK})$, U-pipe spacing $(0.0254,0.0350$ and $0.0500 \mathrm{~m})$ and heat carrier fluid (mixture of water and ethylene glycol or pure water). These figures highlight that: (a) the values of $\mathrm{PES}^{5 \text { th- }}$ year, $\Delta \mathrm{CO}_{2}{ }^{\text {th-year }}$ and $\Delta \mathrm{OC}^{\text {5th-year }}$ are always positive, whatever the simulation case is; this means that the proposed plant is always able to reduce the primary energy consumption, the equivalent carbon dioxide emissions as well as the operating costs in comparison to the conventional heating plant, whatever the BTES characteristics are; (b) the values of $\mathrm{PES}^{5 \text { th-year }}$, $\Delta \mathrm{CO}_{2}{ }^{\text {th-year }}$ and $\Delta \mathrm{OC}^{5 \text { th-year }}$ increase with the values of both $\lambda_{\text {soil }}$ and $\lambda_{\text {grout }}$; (c) for given values of both $\lambda_{\text {grout }}$ and U-pipe spacing, the values of $\mathrm{PES}^{\text {th-year }}, \Delta \mathrm{CO}_{2}{ }^{\text {5th-year }}$ and $\Delta \mathrm{OC}^{\text {th-year }}$ significantly increase up to $30 \%, 58 \%$ and $8 \%$, respectively, when $\lambda_{\text {soil }}$ increases from $0.5 \mathrm{~W} / \mathrm{mK}$ to $3.0 \mathrm{~W} / \mathrm{mK}$; (d) for given values of both $\lambda_{\text {soil }}$ and U-pipe spacing, the values of PES ${ }^{\text {th-year }}$, $\Delta \mathrm{CO}_{2}{ }^{\text {5th-year }}$ and $\Delta \mathrm{OC}^{5 \text { th-year }}$ considerably improve by $63 \%$, $159 \%$ and $15 \%$, respectively, when $\lambda_{\text {grout }}$ rises from $0.5 \mathrm{~W} / \mathrm{mK}$ to $5.0 \mathrm{~W} / \mathrm{mK}$; (e) for given values of $\lambda_{\text {soil }}$ and $\lambda_{\text {grout }}$, the values of $\mathrm{PES}^{5 \text { th-year }}, \Delta \mathrm{CO}_{2}{ }^{\text {th-year }}$ and $\Delta \mathrm{OC}^{5 \text { th-year }}$ slightly decrease by a variation in terms of U-pipe spacing from $0.0254 \mathrm{~m}$ to $0.0350 \mathrm{~m}$; a small performance improvement is observed in the case of the U-pipe spacing increases from $0.0350 \mathrm{~m}$ to $0.0500 \mathrm{~m}$; (f) the heat carrier fluid typology has a small impact in terms of PES ${ }^{\text {th-year }}$, $\Delta \mathrm{CO}_{2}{ }^{\text {5th-year }}$ and $\Delta \mathrm{OC}^{\text {5th-year }} ;(\mathrm{g})$ with reference to the simulation cases 1-27 using a water/ethylene glycol mixture as heat carrier fluid, the best values of $\mathrm{PES}^{5 \text { th-year }}(6.96 \%), \Delta \mathrm{CO}_{2}{ }^{\text {5th-year }}$ $(4.43 \%)$ and $\Delta \mathrm{OC}^{5 \text { th-year }}(17.93 \%)$ are obtained in the simulation case $27\left(\lambda_{\text {soil }}=3.00 \mathrm{~W} / \mathrm{mK}, \lambda_{\text {grout }}=5.00 \mathrm{~W} / \mathrm{mK}, U\right.$ - 
pipe spacing $=0.0500 \mathrm{~m})$; (h) with reference to the simulation cases 28-54 using pure water as heat carrier fluid, the maximum values of $\mathrm{PES}^{\text {th-year }}(7.13 \%), \Delta \mathrm{CO}_{2}{ }^{\text {th-year }}(4.62 \%)$ and $\Delta \mathrm{OC}^{5 \text { th-year }}(18.06 \%)$ are obtained in the simulation case $54\left(\lambda_{\text {soil }}=3.00 \mathrm{~W} / \mathrm{mK}, \lambda_{\text {grout }}=5.00 \mathrm{~W} / \mathrm{mK}\right.$, U-pipe spacing $=$ $0.0500 \mathrm{~m})$.
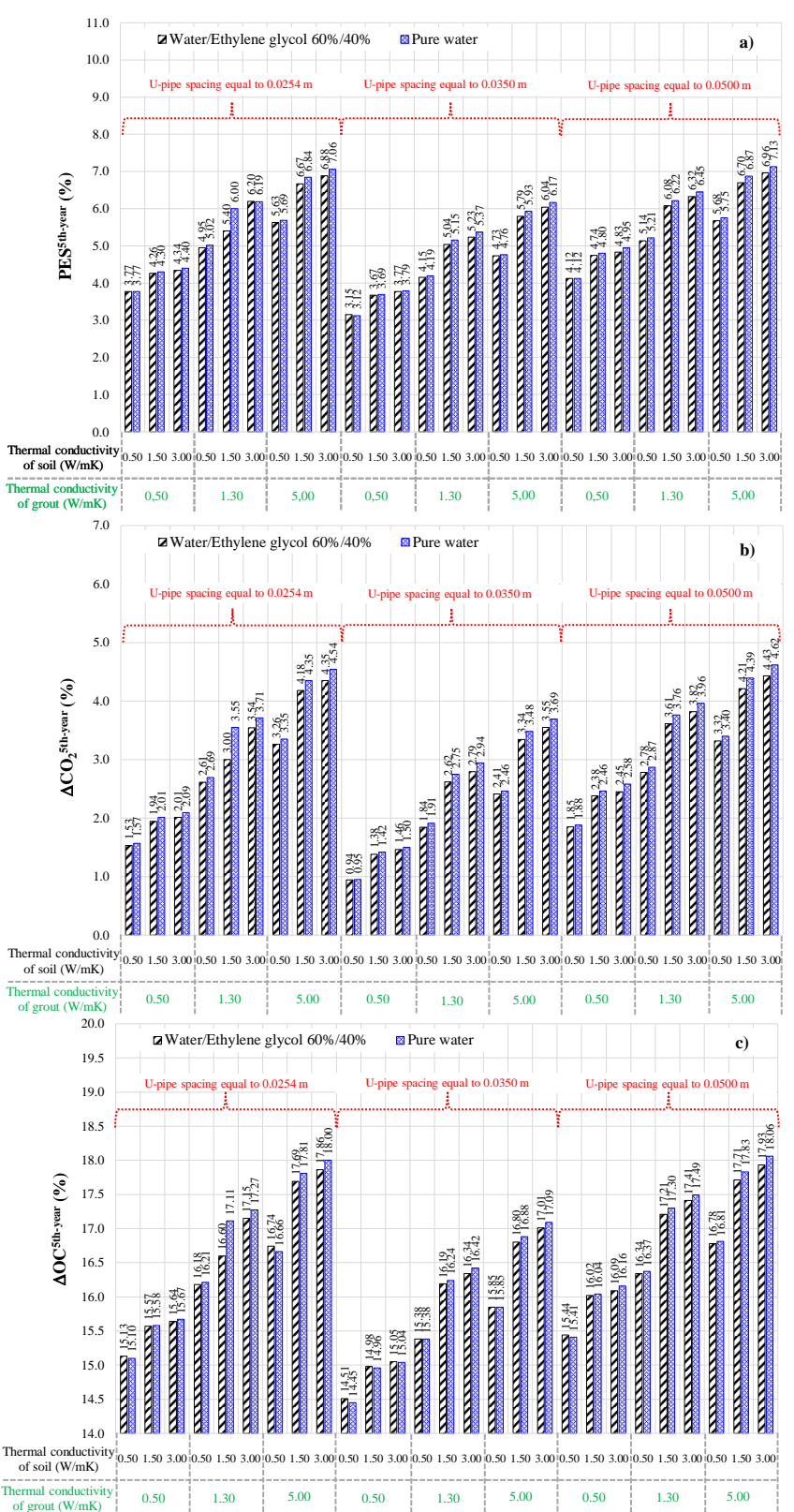

Figure 4. Values of $\mathrm{PES}^{5 \text { th-year }}$ (a), $\Delta \mathrm{CO}_{2}{ }^{\text {5th-year }}$ (b) and $\Delta \mathrm{OC}^{5 \text { th- }}$ year $(c)$ during the $5^{\text {th }}$ year of simulation upon varying the thermal conductivity of soil and grout, U-pipe spacing and heat carrier fluid

The difference in terms of $\mathrm{PES}^{5 \text { th-year }}, \Delta \mathrm{CO}_{2}{ }^{5 \text { th-year }}$ and $\Delta \mathrm{OC}^{\text {th-year }}$ between the configurations 27 (water/ethylene glycol mixture) and 54 (pure water) is almost negligible, so that the simulation case 27 can be assumed as the best case taking into account that the addition of glycol to water yields a solution with a freezing point below that of water, allowing to operate also when the outdoor temperature is lower than $0{ }^{\circ} \mathrm{C}$.

Figures $5 \mathrm{a}, 5 \mathrm{~b}$ and $5 \mathrm{c}$ report the main energy flows during the $5^{\text {th }}$ year of operation associated to the main plant components as a function of $\lambda_{\text {soil }}, \lambda_{\text {grout }}$ and U-pipe spacing, in the case of the mixture of water and ethylene glycol is used as heat carrier fluid.

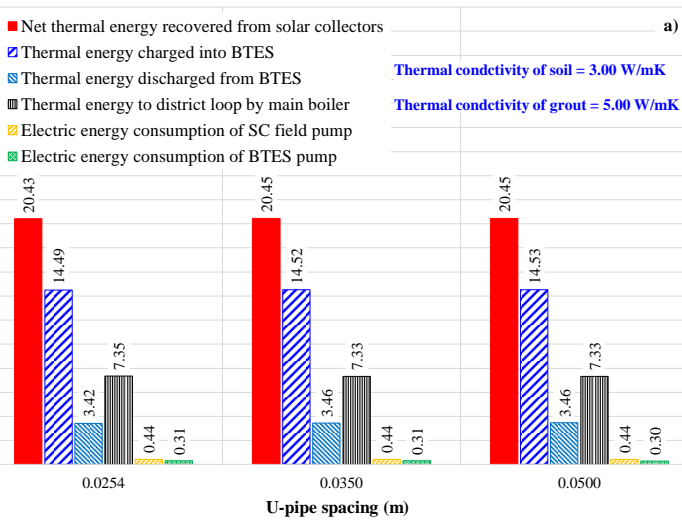

- Net thermal energy recovered from solar collectors ఐThermal energy charged into BTES \$Thermal energy discharged from BTES mThermal energy to district loop by main boile Electric energy consumption of SC field pump Electric energy consumption of BTES pump Electric energy consumption of BTES
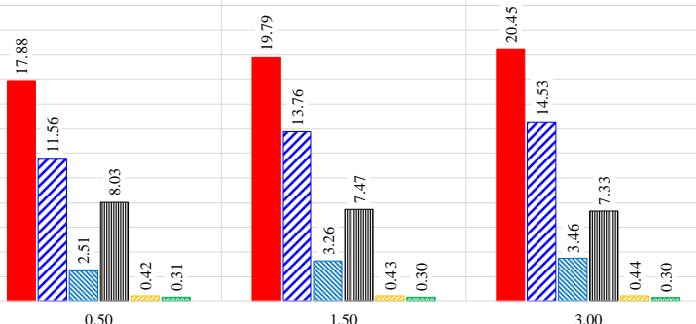

Thermal conductivity of soil (W/mK)

- Net thermal energy recovered from solar collector

$\square$ Thermal energy charged into BTES

\$ Thermal energy discharged from BTES

هThermal energy to district loop by main boiler

Electric energy consumption of SC field pump

圆 Electric energy consumption of BTES pump
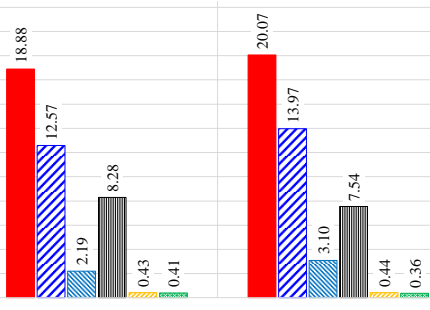

Thermal conductivity of grout $(\mathrm{W} / \mathrm{mK})$

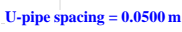

Thermal condctivity of soil $=3.00 \mathrm{~W} / \mathrm{mK}$
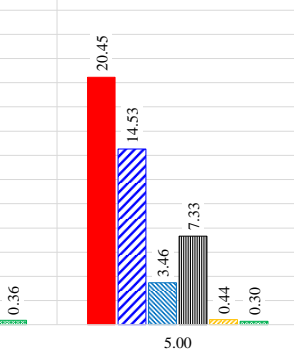

Figure 5. Energy flows associated to the main plant components as a function of U-pipe spacing (a), $\lambda_{\text {soil }}(\mathrm{b})$ and $\lambda_{\text {grout }}(\mathrm{c})$

These figures show that: (a) for given values of $\lambda_{\text {soil }}$ and $\lambda_{\text {grout }}$, the U-pipe spacing scarcely affects the performance of the BTES; (b) for given values of U-pipe spacing and $\lambda_{\text {grout }}$, in the case of $\lambda_{\text {soil }}$ increases from $0.5 \mathrm{~W} / \mathrm{mK}$ to $3.0 \mathrm{~W} / \mathrm{mK}$ (i) the thermal energy recovered from solar collectors increases by about $14 \%$, (ii) the thermal energy injected into the BTES is enhanced by about $26 \%$ and (iii) the thermal energy discharged from the BTES becomes about $38 \%$ larger (together with a corresponding reduction of the thermal energy supplied by the boiler by around $9 \%$ ); (c) for given values of U-pipe spacing and $\lambda_{\text {soil, }}$ when $\lambda_{\text {grout }}$ increases from $0.5 \mathrm{~W} / \mathrm{mK}$ to $5.0 \mathrm{~W} / \mathrm{mK}$ (i) the thermal energy recovered from solar collectors increases by about $8 \%$, (ii) the thermal energy injected into the BTES becomes about $16 \%$ greater and (iii) the thermal energy discharged from the BTES is enhanced by about $58 \%$ (allowing for a reduction of thermal energy provided by the boiler by about $12 \%$ ).

\subsection{Effects of BHEs arrangement}

Figure 6 reports the values of $\mathrm{PES}, \Delta \mathrm{CO}_{2}$ and $\triangle \mathrm{OC}$ during the 
$5^{\text {th }}$ year of operation as a function of the simulation cases 55-67 (see Table 5) characterized by a different (i) number of BHEs, and/or (ii) BHEs connection. The configurations 55-67 are characterized by the same $\lambda_{\text {soil }}(3.0 \mathrm{~W} / \mathrm{mK}), \lambda_{\text {grout }}(5.0 \mathrm{~W} / \mathrm{mK})$, U-pipe spacing $(0.0500 \mathrm{~m})$ and heat carrier fluid (mixture of water and ethylene glycol) of the simulation case 27 (recognized as the best configuration based on the analysis performed in the previous section 6.1).

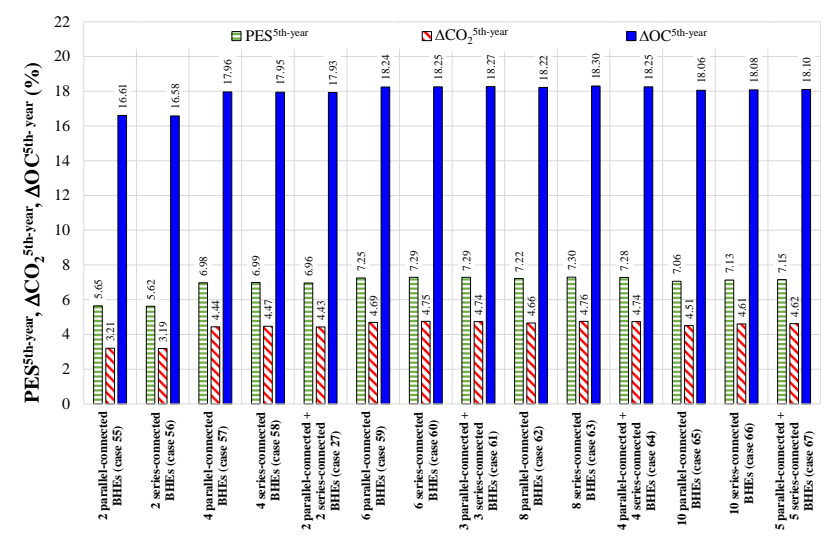

Figure 6. Values of PES, $\Delta \mathrm{CO}_{2}$ and $\triangle \mathrm{OC}$ during the $5^{\text {th }}$ year of operation as a function of BHEs arrangement

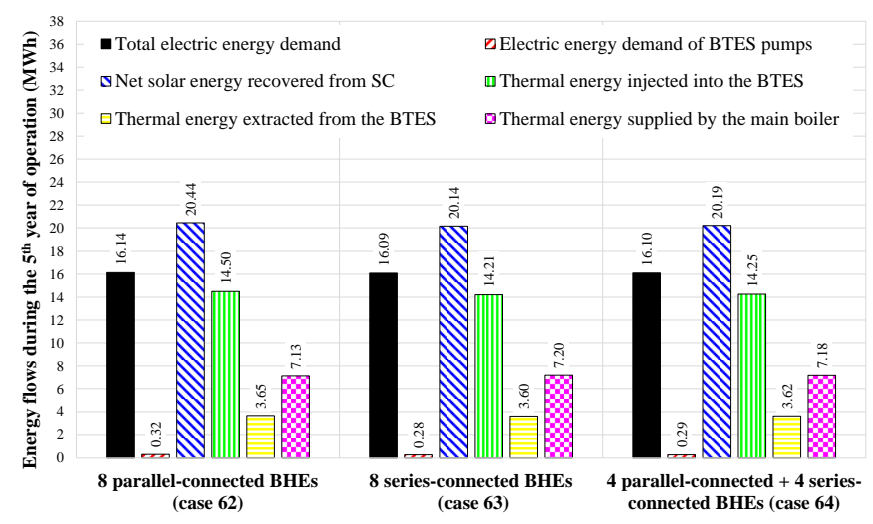

Figure 7. Energy flows during the $5^{\text {th }}$ year of operation for the configurations with 8 BHEs

Figure 6 shows that: (a) the values of PES ${ }^{5 \text { th-year }}, \Delta \mathrm{CO}_{2}{ }^{5 \text { th-year }}$ and $\Delta \mathrm{OC}^{5 \text { th-year }}$ are always positive, whatever the simulation case is; this means that all the proposed configurations of the CSHPSS allow to always reduce the primary energy consumption, the equivalent $\mathrm{CO}_{2}$ emissions as well as the operating costs in comparison to the reference heating system; (b) in the case of series-connected BHEs, the values of $\mathrm{PES}^{5 \text { th- }}$ year,$\Delta \mathrm{CO}_{2}{ }^{\text {th-year }}$ and $\Delta \mathrm{OC}^{\text {th-year }}$ increase with the number of BHEs up to reaching the maximum values when the number of borehole heat exchangers is equal to 8 and then slightly decrease. The maximum values of PES $^{5 \text { th-year }}(7.30 \%)$, $\Delta \mathrm{CO}_{2}{ }^{\text {th-year }}(4.76 \%)$ and $\Delta \mathrm{OC}^{\text {th-year }}(18.30 \%)$ are obtained in the case with 8 series-connected boreholes (simulation case 63 ). Figure 7 reports the main energy flows associated to the proposed system during the $5^{\text {th }}$ year of simulation for the cases of configurations with 8 boreholes; in particular, the total electric energy demand, the electric demand of BTES pump, the net solar energy recovered from solar collectors, the thermal energy injected/extracted into/from the BTES and the thermal energy supplied by the MB are reported. From this figure, it can be derived that, in comparison with the cases 62 (8 parallel- connected BHEs) and 64 (4 parallel-connected +4 seriesconnected BHEs), the configuration 63 with 8 series-connected BHEs is able to minimize the values of both total electric energy demand and electric energy consumption of BTES pumps; this allows to maximize the potential savings in terms of primary energy consumption, carbon dioxide equivalent emissions and operating costs (even if, in comparison to the cases 62 and 64, the solar energy extracted from the BTES is slightly lower and the thermal energy supplied by the boiler is a bit greater).

\section{CONCLUSION}

A parametric analysis has been performed in order to investigate the performance of a centralized hybrid solar district heating network integrated with a seasonal borehole thermal energy storage upon varying the (i) thermal conductivity of soil, (ii) thermal conductivity of grout, (iii) Upipe spacing, (iv) heat carrier fluid, (v) number of BHEs as well as (vi) type of BHEs connection (series, parallel o mixed). The simulation results highlighted that: (a) the proposed system is always able to reduce the primary energy consumption (up to $7.30 \%$ ), carbon dioxide emissions (up to $4.76 \%$ ) and operating costs (up to $18.30 \%$ ) in comparison to a conventional Italian decentralized heating system, whatever the CSHPSS configuration is; (b) the values of $\mathrm{PES}^{\text {th-year }}$, $\Delta \mathrm{CO}_{2}{ }^{5 \text { th-year }}$ and $\Delta \mathrm{OC}^{5 \text { th-year }}$ significantly increase with the thermal conductivity of both grout and soil; (c) the U-pipe spacing a well as the heat carrier fluid have a negligible influence on the overall performance of the district heating network; (d) for a given type of BHEs connection, the values of $\mathrm{PES}^{5 \text { th-year }}, \Delta \mathrm{CO}_{2}{ }^{5 \text { th-year }}$ and $\Delta \mathrm{OC}^{\text {th-year }}$ increase with the number of BHEs up to reaching the maximum values in the case of the number of borehole heat exchangers is equal to 8 and then slightly decrease; (e) for a given number of BHEs, the values of $\mathrm{PES}^{\text {th-year }}, \Delta \mathrm{CO}_{2}{ }^{5 \text { th-year }}$ and $\Delta \mathrm{OC}^{\text {th-year }}$ are maximized in the cases of the boreholes are series-connected, even if the effects of BHEs connection is not particularly significant.

\section{ACKNOWLEDGMENT}

This work was undertaken as part of the research project titled "Solar smart Energy Networks integrated with borehole thermal Energy storages serving small-scale districts in the Campania region" - S.E.N.E.CA. (CUP: B68D19001880005) funded by the "V:ALERE 2019 program" of the University of Campania Luigi Vanvitelli (Italy).

\section{REFERENCES}

[1] Rad, F.M., Fung, A.S. (2016). Solar community heating and cooling system with borehole thermal energy storage-Review of systems. Renewable and Sustainable Energy $\quad$ Reviews, 60: 1550-1561. https://doi.org/10.1016/j.rser.2016.03.025

[2] Carpaneto, E., Lazzeroni, P., Repetto, M. (2015). Optimal integration of solar energy in a district heating network. Renewable Energy, 75: 714-721. https://doi.org/10.1016/j.renene.2014.10.055

[3] Xu, J., Wang, R. Z., Li, Y. (2014). A review of available technologies for seasonal thermal energy storage. Solar Energy,

610-638. 
https://doi.org/10.1016/j.solener.2013.06.006

[4] Hesaraki, A., Holmberg, S., Haghighat, F. (2015). Seasonal thermal energy storage with heat pumps and low temperatures in building projects-A comparative review. Renewable and Sustainable Energy Reviews, 43: 1199-1213. https://doi.org/10.1016/j.rser.2014.12.002

[5] Flynn, C., Sirén, K. (2015). Influence of location and design on the performance of a solar district heating system equipped with borehole seasonal storage. Renewable Energy, 81: 377-388. https://doi.org/10.1016/j.renene.2015.03.036

[6] IEA-SHC. IEA-SHC - Task 32 - Advanced storage concepts for solar and low energy buildings' n.d. http://task32.iea-shc.org/ (accessed May 20, 2020).

[7] IEA SHC. IEA SHC - Task 45 - Large Systems: Large Solar Heating/Cooling Systems, Seasonal Storage, Heat Pumps n.d. http://task45.iea-shc.org/ (accessed May 20, 2020).

[8] Lottner, V., Schulz, M. E., Hahne, E. (2000). Solarassisted district heating plants: Status of the German programme Solarthermie-2000. Solar Energy, 69(6): 449-459. https://doi.org/10.1016/S0038092X(00)00125-0

[9] Wołoszyn, J., Gołaś, A. (2014). Sensitivity analysis of efficiency thermal energy storage on selected rock mass and grout parameters using design of experiment method. Energy Conversion and Management, 87: 1297-1304. https://doi.org/10.1016/j.enconman.2014.03.059

[10] Talebi, B., Haghighat, F., Tuohy, P., Mirzaei, P.A. (2019). Optimization of a hybrid community district heating system integrated with thermal energy storage system. Journal of Energy Storage, 23: 128-137. https://doi.org/10.1016/j.est.2019.03.006

[11] Barberis, S., Rivarolo, M., Traverso, A., Massardo, A.F. (2016). Thermo-economic analysis of the energy storage role in a real polygenerative district. Journal of Energy Storage, 5: 187-202. https://doi.org/10.1016/j.est.2016.01.001

[12] Zanghirella, F., Canonaco, J., Puglisi, G., Di Pietra, B. (2016). Introducing solar thermal "net metering" in an actual small-scale district heating system: A case-study analysis. Energy Procedia, 101: 240-248. https://doi.org/10.1016/j.egypro.2016.11.031

[13] Carotenuto, A., Figaj, R.D., Vanoli, L. (2017). A novel solar-geothermal district heating, cooling and domestic hot water system: Dynamic simulation and energyeconomic analysis. Energy, 141: 2652-2669. https://doi.org/10.1016/j.energy.2017.08.084

[14] Di Pietra, B., Zanghirella, F., Puglisi, G. (2015). An evaluation of distributed solar thermal "net metering" in small-scale district heating systems. Energy Procedia, 78: 1859-1864. https://doi.org/10.1016/j.egypro.2015.11.335

[15] Buoro, D., Pinamonti, P., Reini, M. (2014). Optimization of a Distributed Cogeneration System with solar district heating. Applied Energy, 124: 298-308. https://doi.org/10.1016/j.apenergy.2014.02.062

[16] Panno, D., Buscemi, A., Beccali, M., Chiaruzzi, C., Cipriani, G., Ciulla, G., Bonomolo, M. (2019). A solar assisted seasonal borehole thermal energy system for a non-residential building in the Mediterranean area. Solar Energy, 192: 120-132. https://doi.org/10.1016/j.solener.2018.06.014

[17] TRNSYS. The transient energy system simulation tool n.d. http://www.trnsys.com

[18] Ciampi, G., Rosato, A., Sibilio, S. (2018). Thermoeconomic sensitivity analysis by dynamic simulations of a small Italian solar district heating system with a seasonal borehole thermal energy storage. Energy, 143: 757-771. https://doi.org/10.1016/j.energy.2017.11.029

[19] Richardson, I., Thomson, M., Infield, D., Clifford, C. (2010). Domestic electricity use: A high-resolution energy demand model. Energy and Buildings, 42(10): 1878-1887. https://doi.org/10.1016/j.enbuild.2010.05.023

[20] Jordan, U., Vajen, K. (2001). Realistic Domestic HotWater Profiles in Different Time Scales.

[21] Kloben. FSK model n.d. http://www.kloben.it/products/view/3 (accessed January 13, 2020).

[22] Paradigma. PS series n.d. http://www.paradigmaitalia.it/serbatoio-accumuloacqua-calda-riscaldamento/boiler-accumulo-acquacalda/accumulo-solare-termico.

[23] Vaillant. atmoTEC exclusive VMW n.d. https://www.vaillant.it/home/prodotti/atmotecexclusive-vmw-9664.html.

[24] Hellström, G. (1989). Heat Storage in the Ground, Duct ground heat storage model, Manual for Computer Code. Department of Mathematical Physics, University of Lund, Box 118, S-221 00 Lund, Sweden.

[25] Pahud, D. (2000). Central solar heating plants with seasonal duct storage and short-term water storage: design guidelines obtained by dynamic system simulations. Solar Energy, 69(6): 495-509. https://doi.org/10.1016/S0038-092X(00)00119-5

[26] EnergyPlus. Weather data, EnergyPlus energy simulation software n.d. http://apps1.eere.energy.gov/buildings/energyplus.

[27] Casasso, A., Sethi, R. (2014). Sensitivity analysis on the performance of a ground source heat pump equipped with a double U-pipe borehole heat exchanger. Energy Procedia, 59: 301-308. https://doi.org/10.1016/j.egypro.2014.10.381

[28] Angrisani, G., Canelli, M., Roselli, C., Russo, A., Sasso, M., Tariello, F. (2017). A small scale polygeneration system based on compression/absorption heat pump. Applied Thermal Engineering, 114: 1393-1402. https://doi.org/10.1016/j.applthermaleng.2016.10.048

[29] Chicco, G., Mancarella, P. (2008). Assessment of the greenhouse gas emissions from cogeneration and trigeneration systems. Part I: Models and indicators. Energy, 33(3): 410-417. https://doi.org/10.1016/j.energy.2007.10.006

[30] ARERA, Italian Regulatory Authority for Energy, Networks and Environment n.d. https://www.arera.it/it/inglese/index.htm. 